\title{
Study of Post-COVID-19 Employability in Peru through a Dynamic Model, Between 2020 and 2025
}

\author{
Richard Ronny Arias Marreros ${ }^{1}$, Keyla Vanessa Nalvarte Dionisio ${ }^{2}$, Luis Alberto Romero Tuanama ${ }^{3}$, \\ Juber Alfonso Quiroz Gutarra ${ }^{4}$, Laberiano Andrade-Arenas ${ }^{5}$ \\ Facultad de Ciencias e Ingeniería \\ Universidad de Ciencias y Humanidades
}

\begin{abstract}
The research work is focused on the sector of the population that will have a job, taking into account that the pandemic was a problem that resulted in many people losing their jobs due to the economic crisis that affected all countries because the first half of the year 2020 the equivalent of 400 million full-time jobs were lost and there was a $14 \%$ drop in working hours worldwide, also in Lima 1.2 million people were left without work. For this reason, a dynamic analysis was developed for the projection of post-COVID19 employability in Peru from 2020 to 2025 to obtain an approximate knowledge of the population's labor outlook, implementing system dynamics as a methodology since it includes this recommendation, given that any model built through its application will be based on the opinion of those involved in the system to be represented. In this work, system dynamics is presented as a very useful methodology for the analysis of complex problems, developing the Forrester and causal diagram with the help of Vensim software. As a result, the approximate number of jobs that will be available was visualized, and it was observed that the future of employability will be at risk, which is why a good government strategy is necessary so that this does not happen since people need to satisfy their professional, economic and development needs.
\end{abstract}

Keywords-Employability; forrester diagram; population; system dynamics; vensim

\section{INTRODUCTION}

In the month of December 2019, there were a large number of cases of severe pneumonia that started in the City of Wuhan in China. Initial epidemiological studies showed that the disease was spreading rapidly, affecting more people aged 39 and 79 with an overall lethality [1]. The outbreak spread rapidly in number of cases and in different regions of China during the months of January and February 2020. The disease, which is now called COVID-19, continued to spread in other Asian countries and then to other continents [2].

On March 11, 2020, the World Health Organization (WHO) issued a statement on the occurrence of the pandemic, calling on all countries to take action and increase control efforts in what appears to be the greatest global public health emergency of modern times [3]. However, as of April 2020, more than 2.6 million cases have been confirmed worldwide, with an estimated 180,000 deaths and more than 700,000 patients recovered, numbers that change daily today, and can be monitored in real time on the Johns Hopkins University website [4].

Currently Peru has 32,162,184 inhabitants and up to November 25, 2020 there are 35,685 people who died from COVID-19, in the last day 44 people have died, a lower figure than the previous day, in addition there are 952,439 people confirmed to have been infected. In 2019,515 people died per day, a figure that this year could be increased by the number of deaths from coronavirus. The death rate (deaths compared to confirmed) is $3.75 \%$ [5].

Meanwhile, that is why the effect it is having on the world's labor markets is unprecedented. In the United States, 16.8 million people have applied for unemployment benefits during the last 3 weeks (from March 19 to April 9), a number that has never been presented in American history[6].

Consequently, the unemployment rate in Peru has only exceeded $10 \%$ of the economically active population. This shows that the main problem of the Peruvian labor market is not the number of unemployed, but rather the quality of employment. Therefore, according to data from the National Institute of Statistics (INEI), employment in the country implies the loss of more than 6 million jobs in the second quarter of the year [7]. So the whole world of work is deeply affected by the global pandemic virus. In addition to being a threat to public health, the economic and social uncertainty jeopardizes the long-term livelihoods and well-being of millions of people. It has generated distrust, collective fear, uncertainty and has further evidenced the high level of poverty and informality, especially the lack of protection in some jobs [8].

To know what a System Dynamic is in the first place, we will start by system. This term is used frequently, although with different exceptions. In the same way we talk about a system, as a way of doing, so we say that we have a system to solve a problem or to reach an objective. This means, that formally we talk about a system as an object with some complexity, formed by coordinated parts, so that the whole has a certain unity, which is precisely the system [9]. Systems Dynamics is based on the use of two types of diagrams, Causal Diagrams and Forrester Diagrams, which have their origin in General Systems Theory and are in fact like two sides of the same coin [10].

The importance of the research is to obtain a future vision of the post-pandemic labor outlook so that the state and the population can take measures in this regard, however, there are limitations such as obtaining accurate information on the rates (employability, birth rate, mortality, etc.) that are important parameters for the projection of employability and the lack of articles related to the subject.

The objective of the article is to carry out a dynamic 
modeling of the post-COVID-19 employability projection in Peru during the years 2020 to 2025 .

The rest of the document was organized as follows, section II the literature review of the problem, methodology and tool, section III the System Dynamics methodology, section IV the discussions, $\mathrm{V}$ the results and finally section VI the conclusion and future work.

\section{LiterATURE REVIEW}

The author [11] indicates that the Peruvian population is at risk, not only because of the pandemic but also because of job layoffs.

But the level of unemployment depends on several factors. Also, the reactions of labor market indicators to changes in these factors are different in each country. The situation of the population concerning education, demographics, changes in social norms, and preferences for participation in the labor market are important factors, but in the long term, according to the author [12].

The author [13] mentions that the type of economic disruption likely to affect unemployment and inflation would be a supply shock (a negative supply shock would cause an explosion of inflation so, people would expect higher inflation).

Many of the discussions on inflation start with the Phillips curve, which describes the relationship between unemployment and inflation and also takes into account possible changes in the inflation rate in the future depending on the author [13]. Therefore, the inflation factor is also important for the projection of employability, because it has a close relationship with unemployment.

The author [14] mentions that Dynamic Systems was developed by Forrester, and is useful in the study of the continuous dynamic system, which he applied mainly to the simulation of management and social systems.

The author [15] defines Dynamic Systems as a computerdriven approach to policy analysis and design. The approach uses easy-to-use software that produces mathematical models and is described by sets of differential equations. System dynamics models are flows, accumulation of flows in stocks, feedback between stocks, which is also represented as time delays and flows.

Causal diagrams are directed acyclical charts that encode qualitative assumptions about the causal processes that generate the data. Also, the representation of the causal hypotheses in the graph and the assumptions that allow us to evaluate how these causal hypotheses relate to the observed data according to the author's explanation [16].

For the author [17], the most used software for the simulation of continuous and dynamic processes is Vensim, developed by Window Systems, and it can be used to solve management problems. It has the advantage of being able to be programmed in any programming language and also has the possibility of importing models developed in other software used in modeling and simulation.

Moreover, with, Vensim you can check this large amount of data in a simple or complex way depending on the research topic, which can be used by researchers, students, companies and thus improve the output of a proposed system, as explained [18].

\section{Methodology}

The methodology that will be used is the system dynamics that is a powerful tool that allows translating the problem situations of the systems and projecting conceptual models to give a solution to such problems in which there is high participation of the human being [19].

\section{A. Description of the Problem}

Unemployment in Peru between April and June of this year rose to 8.8 percent, reported the National Institute of Statistics and Information, a period that was strongly marked by the national confinement ordered by the Peruvian government to prevent the spread of COVID-19 in the country.

\section{B. Causal Diagram Design}

Fig. 2 shows the causal diagram, which details the variables and their behavior, within the diagram there are two level variables, the first is population which shows as a result the number of future inhabitants within the country. The population is obtained from a calculation between death, birth, migration and emigration, deaths refer to deaths, if these increase, the population will decrease, this relationship results in a negative loop, on the other hand, if births increase the population will do so in the same way, this is a positive loop, migration refers to the arrival of new inhabitants to the country, if this increases the population will also increase this equally gives us a positive loop; finally, emigration refers to inhabitants leaving the country, if this increases the population decreases, this leaves us a negative loop.

The other level variable is the employed population, this is calculated with contracts, layoffs and population; the more population there is the more possibilities of contracts and this leads to an increase in the employed population, from another point if there is more population there will be more layoffs and this will result in less employed population.

\section{Forrester Diagram Design}

Fig. 1 shows the Forrester diagram, indicating the behavior between various variables categorized in the following aspects:

- Level variables: They are those elements that show us in each instant the situation of the model, present an accumulation, and vary only according to other elements called "flows". The "clouds" within the flow chart are levels of inexhaustible content [21], just like the variable population and currently employed population.

- Flow variables:These are elements that can be defined as temporary functions. It can be said that they collect 


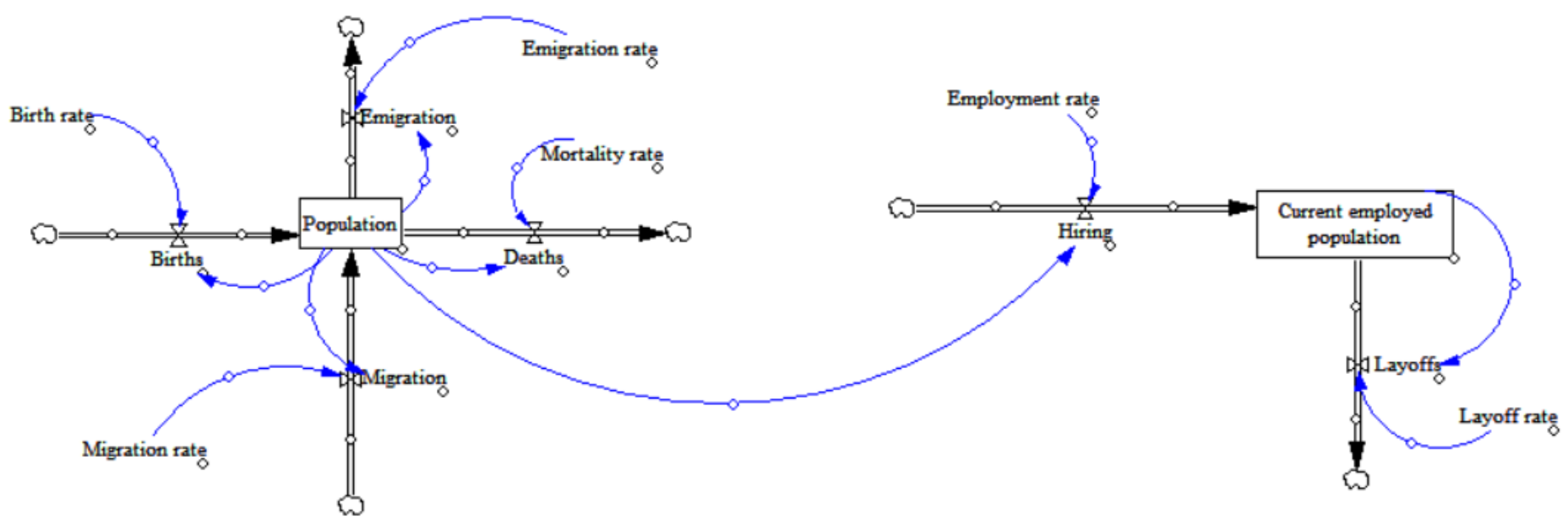

Fig. 1. Forrester Diagram [20].

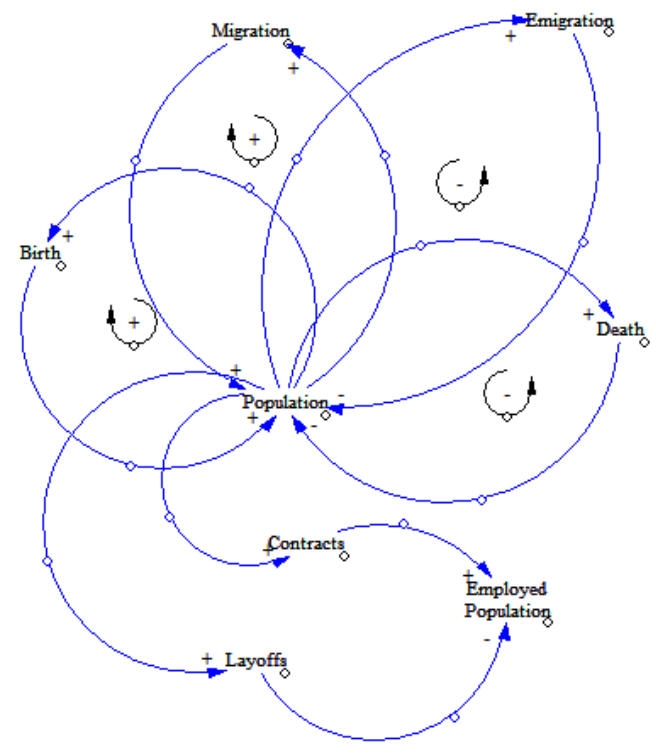

Fig. 2. Causal Diagram [20].

the actions resulting from decisions made in the system, determining the variations in levels [22], as well as the variables births, deaths, migration, emigration, hiring, and firing.

- Parameters: These are the ones that allow better visualization of the aspects that condition the behavior of the flows [23], such as the variables of birth rate, mortality rate, employment rate, and dismissal rate.

\section{Equations}

Table I shows the main level variables which are the population and current employed population. The variation of the main population level will depend on the auxiliary variables or parameters of the birth rate, mortality rate, migration and emigration rate. In the same way, the variation of the main level of the current employed population will depend on the auxiliary variables of the hiring rate and the dismissal rate.

\section{TABLE I. FORMULAS}

\begin{tabular}{|c|c|}
\hline Num. & Formulas \\
\hline 1 & population = emigration + births - migration - deaths \\
2 & population current employee = recruitment - dismissals \\
3 & births = population * birth rate \\
4 & deaths = population / mortality rate \\
5 & emigration = population * emigration rate \\
6 & migration = population * migration rate \\
7 & dismissals = population current employee* $($ redundancy rate/100) \\
8 & hiring = population* $($ employment rate/1000) \\
\hline
\end{tabular}

\section{E. Data}

Table II shows the data entered in the Forrester diagram. The initial population is approximately 32 million, the current employed population is 10 million, the mortality rate is 81.8 per 10000 people, and the birth rate is 17.16 per 1000 born in Peru.

TABLE II. DATA ENTERED IN THE FLOW CHART

\begin{tabular}{|c|c|}
\hline Num. & Data \\
\hline 1 & population (initial value) $=32.162 .184$ \\
2 & Current Employed Population(initial value) $=10.272 .400$ \\
3 & mortality rate $=81.8$ \\
4 & birth rate $=17.16$ \\
5 & emigration rate $=4.7$ \\
6 & migration rate $=2.43$ \\
7 & redundancy rate $=8.8$ \\
8 & employment rate $=53.8$ \\
\hline
\end{tabular}

\section{Discussions}

The dynamic systems development method was used, because it focuses on providing functionalities that correspond to the needs of the problem posed, all changes made during the project are reversible, tests are performed throughout the project's life cycle and quality verification occurs throughout 
the development process and not only at the end of the project [24].

\section{TABLE III. DSDM - SCRUM COMPARISON}

\begin{tabular}{|l|l|}
\hline $\begin{array}{l}\text { Dynamic Systems Develop- } \\
\text { ment Method (DSDM) }\end{array}$ & SCRUM \\
\hline $\begin{array}{l}\text { Product quality is improved } \\
\text { throughout the project cycle. }\end{array}$ & $\begin{array}{l}\text { Knowledge needed to achieve a } \\
\text { goal. }\end{array}$ \\
\hline Ensures rapid developments. & $\begin{array}{l}\text { Involves from the beginning and } \\
\text { gives a role to everyone. }\end{array}$ \\
\hline $\begin{array}{l}\text { It allows changes to be made } \\
\text { easily. }\end{array}$ & $\begin{array}{l}\text { Reduces the cost of change at } \\
\text { all stages. }\end{array}$ \\
\hline $\begin{array}{l}\text { Allows reuse of application } \\
\text { through existing modules. }\end{array}$ & $\begin{array}{l}\text { Visible, transparent by the spe- } \\
\text { cialist team }\end{array}$ \\
\hline
\end{tabular}

On the other hand, if we compare it with the Scrum framework it only works with small teams and short projects, it requires an exhaustive definition of the tasks and their deadlines, also a risk that this agile methodology has is having to go back to the rhythm of work after the abandonment of some member of the team during the development [25], all this is detailed in Table III.

TABLE IV. VENSIM - STELLA COMPARISON

\begin{tabular}{|l|l|}
\hline Vensim & Stella \\
\hline $\begin{array}{l}\text { Make a synthesis of a complex } \\
\text { problem. }\end{array}$ & $\begin{array}{l}\text { Simple interface allows us to } \\
\text { create convincing models close } \\
\text { to reality. }\end{array}$ \\
\hline $\begin{array}{l}\text { To diagnose the evolution of the } \\
\text { analyzed system. }\end{array}$ & $\begin{array}{l}\text { It is not possible to do math- } \\
\text { ematics or very complex pro- } \\
\text { gramming. }\end{array}$ \\
\hline $\begin{array}{l}\text { Create a model of the system } \\
\text { and enter it into the computer. }\end{array}$ & $\begin{array}{l}\text { Create versatile models in terms } \\
\text { of their possible modification } \\
\text { and adaptation to systems. }\end{array}$ \\
\hline $\begin{array}{l}\text { Perform simulations with the } \\
\text { model, aimed at making propos- } \\
\text { als for action }\end{array}$ & $\begin{array}{l}\text { Tests can be easily performed in } \\
\text { different scenarios. }\end{array}$ \\
\hline
\end{tabular}

For the development of the Forrester diagram, the Vensim program was used, since it is currently the most versatile, intuitive, and simple program for simulating dynamic models, it also allows building models through causal diagrams or text version, and in any of the modalities, it allows easily comparing the results of different experiments, superimposing graphs of different variables, changing scales, study periods, among other things [26]. On the other hand, the author [27] mentions the Stella software that is also used to model dynamic systems, however, it has a deficit that only allows it to use little sophisticated mathematics and little programming knowledge, all this is further detailed in Table IV.

\section{RESULTS}

For the results section, statistical tables are shown for the next five years based on the Forrester diagram, both of which give increasing statistical results. These results put the stability of the country at risk and should therefore be carefully evaluated.

Fig. 3 shows that Peru's current population will grow by approximately 2.5 million people between 2020-2025, due to various factors, but the main one is immigration. Peru is a country of transit and reception of Venezuelan migrants, therefore the number of Venezuelan immigrants has grown during the last decade, these are considered the largest group of foreigners in the country[28], due to this excessive immigration, the birth rate increases and the population does the same, if these variables are not maintained or decrease the population in the country would become double of what was predicted.

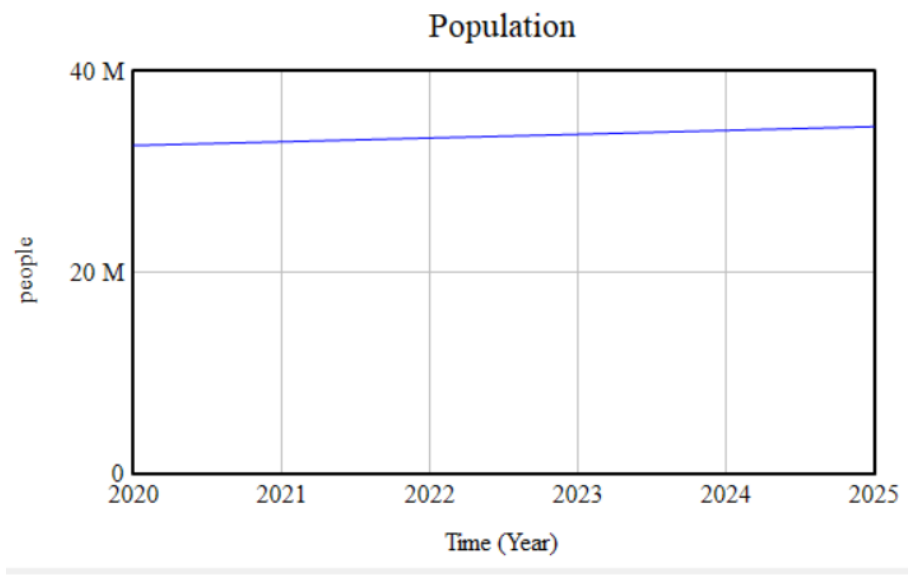

$\square$ Population - simulation

Fig. 3. Population.

Fig. 4 shows that the currently employed population is approximately 10 million people, this will suffer a small growth (compared to the population) of approximately 4 million between 2020-2025, therefore the future of employability is at existential risk, so it is necessary a public policy that benefits Peruvians without harming foreigners since work is the basic and primordial condition of every human being and we can even say that work is an indispensable role in the development of man.

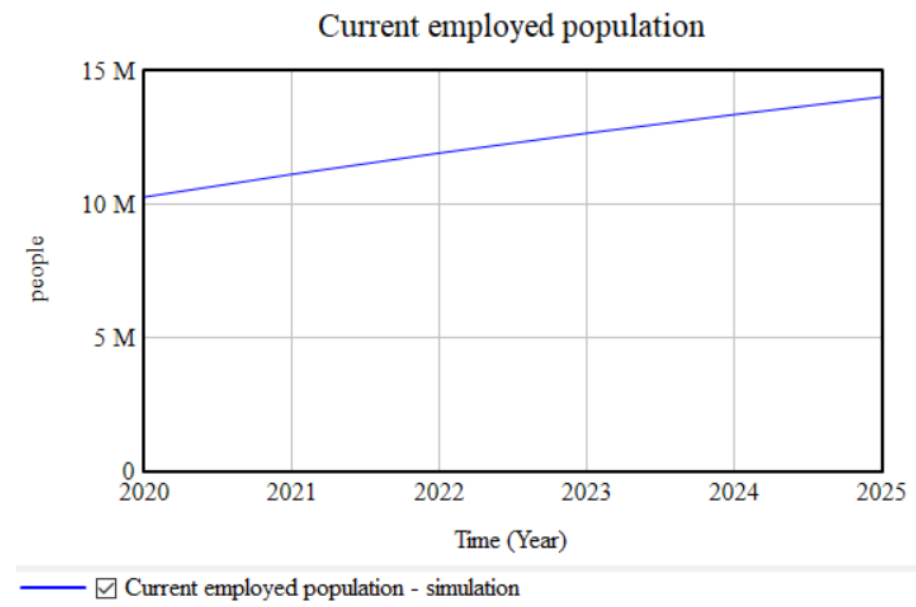

Fig. 4. Current Employed Population.

\section{CONCLUSIONS AND Future Work}

In conclusion, the dynamic systems model for the projection of post-COVID19 employability in Peru between 20202025 was performed, and the results were that the Peruvian population will increase by 2.5 million until 2025 due to immigration, and therefore the birth rate also increased. Concerning employability, during the first months of the pandemic, the 
layoff rate increased, but the projection of the dynamic systems model performed showed that employability will grow slowly, which puts at risk the availability of work for the population that is also growing. Therefore, a public policy that benefits the entire working population would be necessary, since work is indispensable for a person's livelihood. Therefore, the importance of this research work focuses on the decisions that the state and the population itself will make with the results obtained from the projection.

The dynamic methodology of systems that were implemented in the research work is important because it helps to analyze data, visualize through diagrams and understand how systems behave, and also allows the creation of simulation models for the future projection of systems.

As future work it is planned to improve the model of dynamic systems of work, adding more level variables such as inflation, being the auxiliary variable the inflation rate, among other variables more level and auxiliary, however, this would make the dynamic model more complex, but the results of the projection will be more accurate, and thus the model can be implemented in other countries or provinces.

\section{REFERENCES}

[1] Z. Wu and J. M. McGoogan, "Characteristics of and important lessons from the coronavirus disease 2019 (covid-19) outbreak in china: summary of a report of 72314 cases from the chinese center for disease control and prevention," Jama, vol. 323, no. 13, pp. 1239-1242, 2020.

[2] Y.-R. Guo, Q.-D. Cao, Z.-S. Hong, Y.-Y. Tan, S.-D. Chen, H.-J. Jin, K.-S. Tan, D.-Y. Wang, and Y. Yan, "The origin, transmission and clinical therapies on coronavirus disease 2019 (covid-19) outbreak-an update on the status," Military Medical Research, vol. 7, no. 1, pp. 1-10, 2020.

[3] F. J. Díaz-Castrillón and A. I. Toro-Montoya, "Sarscov-2/covid-19: el virus, la enfermedad y la pandemia," Medicina y Laboratorio, vol. 24, no. 3, pp. 183-205, 2020.

[4] C. Courtemanche, J. Garuccio, A. Le, J. Pinkston, and A. Yelowitz, "Strong social distancing measures in the united states reduced the covid-19 growth rate: Study evaluates the impact of social distancing measures on the growth rate of confirmed covid-19 cases across the united states." Health Affairs, pp. 10-1377, 2020.

[5] Expansión, "Perú - covid-19 - crisis del coronavirus." urlhttps://datosmacro.expansion.com/otros/coronavirus/peru/, 2020.

[6] A. A. Montoya, “¿qué efectos tendrá la covid-19 sobre el empleo de américa latina y el caribe?." urlhttps://blogs.iadb.org/trabajo/es/que-efectos-tendra-lacovid-19-sobre-el-empleo-de-america-latina-y-el-caribe/, 2020.

[7] M. Murialdo, "Durísima informe: Desempleo es la pandemia colateral del perú." urlhttp://miningpress.com/coronavirus/332697/durisimoinforme-desempleo-es-la-pandemia-colateral-del-peru/, 2020.

[8] A.-L. Moreno-Huamanchumo, "Plan de comunicación interna para el retorno a oficinas de colaboradores post covid-19 del banco corporativo americano," 2020.
[9] L. R. Izquierdo, J. M. Galán, J. I. Santos, and R. Del Olmo, "Modelado de sistemas complejos mediante simulación basada en agentes y mediante dinámica de sistemas," EMPIRIA. Revista de Metodología de las Ciencias Sociales, no. 16, pp. 85-112, 2008.

[10] J. M. García, "Aplicaciones prácticas de la dinámica de sistemas en un mundo complejo." url:http://www.dinamica-desistemas.com/revista/0307a.html, 2006.

[11] S. L. R. Vela, "Análisis de riesgo existencial y el futuro de la empleabilidad," Phainomenon, vol. 19, no. 1, 2020.

[12] M. Oliskevych and I. Lukianenko, "European unemployment nonlinear dynamics over the business cycles: Markov switching approach," Global Business and Economics Review, vol. 22, no. 4, pp. 375-401, 2020.

[13] O. Shibistiuk, "Modelling inflation and unemployment by using system dynamics," 2018.

[14] W.-T. Yang, "A technique for improving readability of forrester diagram in system dynamics," Yugoslav journal of operations research, vol. 13, no. 1, 2016.

[15] T. Nguyen, S. Cook, and V. Ireland, "Application of system dynamics to evaluate the social and economic benefits of infrastructure projects," Systems, vol. 5, no. 2, p. 29, 2017.

[16] T. R. Cortes, E. Faerstein, and C. J. Struchiner, "Use of causal diagrams in epidemiology: application to a situation with confounding," Cadernos de saude publica, vol. 32, no. 8, 2016.

[17] G. O. Bernardo, J. R. T. Santos, and C. G. M. Miranda, "Aplicação da dinâmica de sistemas na gestão de processos de construção civil-utilização do software vensim/application of systems dynamics in the management of civil construction processes-use of vensim software," Brazilian Journal of Development, vol. 5, no. 7, pp. 7886-7902, 2019.

[18] J. L. Díaz-Martínez, E. GUERRA ALEMAN, H. R. NEIRA MOLINA, J. García-Restrepo, L. Londoño-Lara, and A. VALLE-OSPINO, "Análisis de la dinámica de sistemas en el software vensim," https://www. revistaespacios. com/a19v40n38/19403819. html, 2019.

[19] C. R. Cadenas Anaya, "Modelo basado en dinámica de sistemas para pronóstico de resultados de planificacióninversión y ejecución de proyectos industriales," 2020.

[20] M. Rojas, C. , Pantoja, J. Henao, and R. Murillo, "Dynamic behavior analysis of the gross domestic product in a city in the center of the valle del cauca," ENCUENTRO COLOMBIANO DE DINÁMICA DE SISTEMAS, pp. 9398, 2017.

[21] J. M. Redondo, G. Olivar, D. Ibarra-Vega, and I. Dyner, "Modeling for the regional integration of electricity markets," Energy for sustainable development, vol. 43, pp. 100-113, 2018.

[22] J. J. Cardiel-Ortega, R. Baeza-Serrato, and R. A. Lizarraga-Morales, "Development of a system dynamics model based on six sigma methodology," Ingeniería $e$ Investigación, vol. 37, no. 1, pp. 80-90, 2017.

[23] J. Fernandez, N. Aguilar, R. Fernandez de Canete, J. C. Ramos-Diaz et al., "Causal modeling of the glucoseinsulin system in type-i diabetic patients," 2017.

[24] F. M. Y. Roxas, J. P. R. Rivera, and E. L. M. Gutierrez, "Locating potential leverage points in a systems thinking 
causal loop diagram toward policy intervention," World Futures, vol. 75, no. 8, pp. 609-631, 2019.

[25] M. Kuhrmann, P. Diebold, J. Münch, P. Tell, V. Garousi, M. Felderer, K. Trektere, F. McCaffery, O. Linssen, E. Hanser et al., "Hybrid software and system development in practice: waterfall, scrum, and beyond," in Proceedings of the 2017 International Conference on Software and System Process, 2017, pp. 30-39.

[26] E. A. Lagarda-Leyva, "Collection and distribution of wheat, dynamic of theprocess of shipping to international markets: Case study," Int. J Sup. Chain. Mgt Vol, vol. 8, no. 1, p. 43, 2019.

[27] C. Sbughea, "Simulation of the production process dynamics using vensim and stella." Annals of the University Dunarea de Jos of Galati: Fascicle: I, Economics \& Applied Informatics, vol. 22, no. 1, 2016.

[28] A. Hernández-Vásquez, R. Vargas-Fernández, C. RojasRoque, and G. Bendezu-Quispe, "Factores asociados a la no utilización de servicios de salud en inmigrantes venezolanos en perú," Revista Peruana de Medicina Experimental y Salud Publica, vol. 36, pp. 583-591, 2020. 